\title{
Системний підхід до комплексного застосування методик реабілітації та технічних засобів для дітей з ДЦП
}

\author{
Салєєва А. Д., Чернишова І. М., Логвін Г. Б., Данильчук А. В. \\ Український науково-дослідний інститут протезування, протезобудування та відновлення \\ працездатності, м. Харків, Україна
}

Актуальність. Понад 90 тис. дітей з інвалідністю в Україні, хворих на церебральний параліч, мають обмеження функцій опороспроможності та пересування, що ускладнює ї соціальну адаптацію в суспільстві. 3 них близько 14 тис. проходять курси реабілітації в 126 центрах соціальної реабілітації для дітей $з$ інвалідністю Мінсоцполітики. На даний час не існує системного методологічного підходу до раціонального їх призначення, що ускладнює роботу реабілітаційних центрів.

Метою нашої роботи було створення системи раціонального призначення методик фізичної реабілітації та технічних засобів реабілітації (ТЗР) у дітей з ДЦП.

Матеріали та методи. У систему було покладено класифікацію великих моторних функцій дитини (GMFCS), засновану на етапах її моторного розвитку в певному віці. 3 метою систематизації реабілітаційних заходів, конкретизації ТЗР був розроблений алгоритм вибору методик фізичної реабілітації і ТЗР залежно від віку дитини та ступеня обмеження іï рухових функцій. Були визначені: мета реабілітації, рекомендовані реабілітаційні методики, вид ТЗР та очікуваний ефект для кожної групи дітей відповідного рівня рухової активності та віку (до 2-х років, від 2 до 4 років, від 4 до 6 років, від 6 років).

Результати дослідження та ї обговорення. Система пройшла апробацію в УкрНДІ протезування і чотирьох реабілітаційних центрах та показала свою ефективність в організації реабілітаційної допомоги дітям з ДЦП. Система є допоміжним засобом для правильного вибору методик фізичної реабілітації та ТЗР, що відповідає руховому статусу та віку дитини з ДЦП.

Висновки. Отримані результати застосування системи в практиці дозволяють рекомендувати систему раціонального призначення методик фізичної реабілітації та ТЗР для дітей з ДЦП залежно від рівня рухової активності й віку дитини для широкого застосування в центрах соціальної реабілітації.

Перспективи подальших досліджень: систематизація методик фізичної реабілітації та ТЗР для дітей 3 в'ялими парезами.

Ключові слова: церебральний параліч, системний підхід, реабілітація. 